\title{
Autologous chondrocyte implantation for cartilage repair: current perspectives
}

\author{
This article was published in the following Dove Press journal: \\ Orthopedic Research and Reviews \\ II November 2015 \\ Number of times this article has been viewed
}

\author{
Johannes Zellner' \\ Werner Krutsch' \\ Christian G Pfeifer' \\ Matthias Koch' \\ Michael Nerlich' \\ Peter Angele ${ }^{1,2}$ \\ 'Department of Trauma Surgery, \\ University Medical Center \\ Regensburg, Regensburg, Germany; \\ ${ }^{2}$ Sporthopaedicum, Regensburg, \\ Germany
}

Correspondence: Johannes Zellner Department of Trauma Surgery, University Medical Center Regensburg,

Franz Josef Strauss Allee II, 93042

Regensburg, Germany

Tel +49 94I 9446805

Fax +49 94I 9446806

Email johannes.zellner@ukr.de
Abstract: Over the last decade, regenerative treatment options have become the more routinely used techniques for treatment of cartilage defects, with predictable outcomes for their specific indications. For large chondral lesions in young patients, in particular, autologous chondrocyte implantation is the treatment of choice for restoration of joint health. This review focuses on indications, results, and outcome predictors of autologous chondrocyte implantation in comparison to other regenerative treatment procedures and discusses improvement options and future perspectives for autologous chondrocyte transplantation. As research activities are increasing in the field of regenerative joint therapy, recent developments may help to overcome remaining limitations step by step.

Keywords: ACI, cartilage repair, matrix- associated autologous chondrocyte transplantation, microfracture, osteochondral transplantation

\section{Introduction}

Chondral injuries of the knee have a high incidence. Sellards et al ${ }^{1}$ report chondral injuries in $10 \%-12 \%$ of individuals. Widuchowski et $\mathrm{al}^{2}$ reviewed 25,124 knee arthroscopies to quantify the prevalence, location, and grade of chondral lesions. Approximately $60 \%$ of the patients had cartilage defects, of which $67 \%$ were supposed to be focal. The main locations were retropatellar and medial. In their series of more than 30,000 arthroscopies of the knee, Curl et $\mathrm{al}^{3}$ found high-grade cartilage lesions (Outerbridge grade III and IV) in over $60 \%$ of the patients. The incidence of chondral injuries shows its high impact on the society, as it is generally agreed that the persistence of cartilage defects is a risk factor for joint dysfunction exacerbation, which finally leads to severe osteoarthritis.

However, cartilage lesions can remain symptomless over a long period of time. This may lead to a delayed evaluation and treatment of cartilage injuries that can have tremendous consequences for the joint.

This emphasizes the importance of an adequate treatment of cartilage lesions at the right time in order to prevent early onset and development of osteoarthritis.

Defect size seems to be an important determining factor for progression of cartilage lesions to osteoarthritis. Since the introduction of the technique of autologous chondrocyte implantation (ACI) by Brittberg et $\mathrm{al}^{4}$ in 1994, large size cartilage defects can also be successfully treated regeneratively.

This paper focuses on indications, advantages, and disadvantages of ACI techniques in comparison to other current regenerative treatment options and discusses future perspectives in cartilage treatment by ACI. 


\section{Current treatment options for cartilage repair Bone marrow stimulation techniques}

Among reparative options for cartilage treatment, bone marrow stimulation procedures are the most commonly applied techniques worldwide due to their simplicity and low costs. The aim of this technique is to recruit bone marrow cells via creating a communication between cartilage lesions and subchondral bone to get access to potential cartilage precursor cells. Stem cells migrate from the marrow cavity to the fibrin clot of the defect and lead to the formation of a fibrocartilaginous tissue..$^{5}$ In a systematic review, Mithoefer et $\mathrm{al}^{6}$ found that microfracturing provides effective functional improvement for at least 2 years. Steadman et al, ${ }^{7}$ who described the modern technique of microfracture, reported long-term satisfactory results. In smaller defects, microfracture shows promising results concerning mobility, reduction of pain, and return to sport. ${ }^{8}$ However, recent reports show that over time the results of microfracture are getting worse, especially in active patients and in those with larger chondral defects 5 years after the procedure. Additionally, the effects of microfracture are related to the patient's age, and so older patients do not seem to profit from this specific treatment. ${ }^{6,9-16}$ The repair tissue response can be unpredictable; fibrous soft, spongiform tissue combined with central degeneration is frequently found, and patients may have to adjust their activity level to that of their knee function. ${ }^{17}$ Another reason for the deterioration of the clinical outcome after microfracture over time might be the development of subchondral sclerosis, cysts, or the formation of intralesional osteophytes. A complication rate of up to $50 \%$ after microfracturing is described in literature. ${ }^{18}$ The results published in the literature suggest using these procedures only in the treatment of acute and small lesions, and not in large cartilage defects. ${ }^{6}$

Recently, the technique of microfracturing has been modified to a microdrilling method. The idea of drilling holes through the damaged cartilage area into the subchondral bone marrow space to stimulate repair tissue was first described by Pridie. ${ }^{19}$ Thermal necrosis was a potential disadvantage that could affect the outcome. The improved modern microdrilling version with arthroscopically applicable narrow-caliber drills up to $4 \mathrm{~mm}$ in depth is more reproducible and less traumatic. Therefore, defect preparation and treatment seem to be better controllable. ${ }^{20}$ However, no prospective clinical trial has shown significant improvement of the microdrilling over the original microfracture technique yet. ${ }^{21}$

\section{Autologous osteochondral transplantation}

Focal (osteo-)chondral defects may also be addressed with osteochondral autograft transplantation (OAT). It is the only method to transfer hyaline articular cartilage into the defect area. Harvesting and subsequent implantation of autologous osteochondral plugs is performed in a one-step procedure. The plugs are frequently taken via a small incision from a non-weight-bearing area such as the medial or lateral margin of the trochlea or the intercondylar notch. This procedure guarantees a tissue transfer of viable osteochondral units that aims to integrate via bone-to-bone healing, since the mature cartilage tissue has limited healing potential and rarely fully heals to surrounding cartilage. The fast bone-to-bone integration allows a rehab program with a rapid increase in weight bearing. ${ }^{5}$ In the early 1990s, Hangody conceived and perfected the mosaicplasty technique, which uses multiple small diameter osteochondral plugs that can be implanted also through an arthroscopic approach, and good results have been reported at long-term follow-up, particularly for small defects. ${ }^{17,18}$ Especially deep focal chondral defects with affection of the subchondral plate or small cartilage lesions with pathologies of the subchondral bone like cysts may be responsive to a treatment with OAT. In controlled randomized prospective studies, Gudas et al ${ }^{12,22}$ showed significantly better clinical results after 12,24, and 36 months comparing OAT versus microfracture. However, with increasing defect size, complication rate rises due to integration problems and donor site morbidity. So, treatment of a chondral defect larger than $3-4 \mathrm{~cm}^{2}$ with OAT is no longer recommended in literature. ${ }^{10,23-26}$

\section{Osteochondral allografts}

Large osteochondral defects remain a problem for reconstructive surgery and regenerative treatment. Osteochondral allografts might be a therapeutic alternative. Besides the technically demanding procedure, graft availability is an important issue, which severely reduces the possibility of using these procedures in daily clinical practice. ${ }^{5}$ Since stored grafts do not maintain their biological and biomechanical characteristics, due to loss of chondrocyte vitality and worsening of biomechanical properties, ${ }^{27}$ fresh osteochondral allografts are currently used to preserve tissue vitality. Chondrocyte survival is diminished after freezing, even with existing cryopreservation techniques. However, vital chondrocytes are important to maintain the cartilage matrix, which is critical for long-term functioning of the graft. On the contrary, fresh allografts show satisfactory 
long-term results with graft survival and satisfactory clinical outcome. ${ }^{28}$ Incorporation of these grafts is dependent upon the healing of host bone to allograft bone by creeping substitution. ${ }^{29}$ Immunology of the fresh allografts is not considered clinically important at this time. However, graft DNA is detectable over more than 30 years after transplantation in the osteochondral allograft. ${ }^{30}$ Unfortunately, although this technique has been successfully used for the treatment of large chondral defects, there are still some concerns. The low availability and the difficulties in the preservation and management of the fresh allografts and the possible risk of disease transmission reduce the indication and the wider use of this procedure. ${ }^{5}$

\section{Autologous chondrocyte transplantation}

In recent years, matrix-guided autologous chondrocyte transplantation (MACT) for the treatment of large full-thickness articular cartilage defects is becoming more popular. Brittberg et $\mathrm{al}^{4}$ first introduced the technique of the ACI in 1994. Particularly for the treatment of cartilage defects larger than $3 \mathrm{~cm}^{2}$, the ACI revealed superior long-term success. ${ }^{31-33}$ The conventional technique is accompanied with periosteum harvest and fixation over the cartilage defects via large skin incisions. Autologous chondrocytes were injected underneath the periosteal flap. Hypertrophy of the periosteum with high rate of revision arthroscopies ${ }^{34}$ and the risk of transplant failure of up to $20 \%$ are major drawbacks of the conventional ACI.

The MACT was developed to address these problems. In a first arthroscopy, small osteochondral plugs are taken from the non-weight-bearing cartilage adjacent to the lateral femoral notch. Then the chondrocytes are isolated, cultured, and seeded on biodegradable scaffolds. Approximately 3 weeks after the first arthroscopy, the cell-seeded scaffolds are implanted in cartilage defects with sutures or biodegradable devices like plugs or anchors.

With the new technique of the MACT, some disadvantages of the ACI could be eliminated..$^{35}$ The rate of hypertrophy of the transplant or periosteum was reduced by the matrix-guided technique. ${ }^{35,36}$

Compared to other reconstructive therapy options for cartilage defects, like microfracturing or OAT, the MACT shows the best quality of the regenerated tissue. ${ }^{37}$

Especially for full-thickness cartilage defects larger than $4 \mathrm{~cm}^{2}$, the MACT is the recommended therapy in literature. Other cartilage therapy procedures failed to improve the clinical outcome of large cartilage defects. ${ }^{10,38}$

For deep osteochondral defects, the MACT can be combined with bone augmentation like cancellous bone grafting or autologous bone transplantation, eg, from the iliac crest.

In a controlled randomized prospective study, Bentley et $\mathrm{al}^{31}$ showed significantly better outcome results after ACI compared to OAT.

The best clinical results of the MACT can be seen in traumatic chondral lesions and in osteochondrosis dissecans. On the other hand, degenerative cartilage defects and chronic lesions are still problematic to treat. Especially, patients with a long history of pain show a significantly worse outcome after MACT. ${ }^{32,34,39-44}$

In a recently published study, Vanlauwe et $\mathrm{al}^{45}$ compared ACI with microfracture and showed a significant improvement of patients' outcome after MACT when the symptoms of the cartilage lesion did not last more than 3 years. On the other hand, in patients with clinical symptoms more than 3 years, ACI failed to improve the functional outcome significantly compared to microfracture. The earlier a biological cartilage repair is performed, the better are the clinical results. ${ }^{10,39,41,45}$ Thus, primary cartilage defects should be treated as soon as possible to improve the long-term outcome..$^{10,45}$

Another problem for biological cartilage repair besides the delay of treatment is the localization of the defect. Results of all treatment options behind the patella are worse than in other parts of the knee joint. ${ }^{31,46-49}$ Probably the special biomechanical situation in the retropatellar area is the reason for the higher rate of cartilage treatment failure. As this is not a problem of a specific cartilage repair procedure, the necessity arises to address all pathologies for a successful cartilage treatment behind the patella. Comparable to osteotomy or meniscal repair in the femorotibial part in the retropatellar area, all pathologies like maltracking of the patella or dysplasia should be corrected. ${ }^{50}$

In a controlled randomized prospective study for large size chondral defects $\left(4-10 \mathrm{~cm}^{2}\right)$, the outcome after MACT was significantly better after 2 years compared to microfracture. ${ }^{51}$ Similar long-term results were seen for active patients comparing MACT with microfracture. ${ }^{8}$ In another randomized prospective study, Crawford et $\mathrm{al}^{52}$ saw significantly more therapy responders in the MACT group compared to the microfracture group after 6,12 , or 24 months. These results correlated to the clinical and functional outcome of the patients in the KOOS (Knee Injury and Osteoarthritis Outcome Score) and IKDC (International Knee Documentation Committee) score.

The reason for the superior results after MACT compared to microfracture might be the better defect filling, histological results, and the lack of osteophytes in the defect site or 
the regenerated tissue, which can be predominantly seen 4 or 5 years after microfracture (Figure 1). 6,9,47,53

However, if microfracture fails as primary procedure for treatment of a chondral defect, the risk of a treatment failure after the secondary performed MACT rises significantly. For that reason, some authors do not recommend microfracture as a first-line treatment, especially for larger defects. ${ }^{54-56} \mathrm{On}$ the other hand, there are reports in literature that show good results of MACT even as a second-line therapy procedure. ${ }^{41,57}$ Additionally, the age-related effects of a cartilage therapy seem to be less significant with the MACT in comparison to microfracture. . $^{6,13,15,41,58-60}$

Macroscopic and histological findings play an important role after MACT. For the evaluation of the quality of the regenerated tissue, not only histological findings but also the amount of defect filling, the surface quality, and the integration into the surrounding native cartilage are important. ${ }^{37}$

It has been shown that differentiated complete defect filling correlates with good clinical results. On the other hand, incomplete defect filling with undifferentiated scar tissue reveals unsatisfying scoring results with ongoing pain and worse joint function of the patients. ${ }^{17,61-63}$ This effect can be particularly seen in larger chondral defects. In a pilot study, we reported that the transplant quality is adequate at the time of surgery of MACT. We retrospectively reviewed 125 patients with large localized cartilage defects (mean defect size $5 \mathrm{~cm}^{2}$ ) of the knee who were treated with MACT. Portions of the cell-matrix constructs that were not implanted in the cartilage defects were further cultured and tested for their potential to form articular cartilage. In vitro assessment of the cell-matrix implants showed chondrogenic differentiation with positive staining for glycosaminoglycans and collagen II in all cultures. Enzyme-linked immunosorbent assay showed an increase of collagen II production. Clinically, we observed an improvement in median IKDC score from 41 to 67 points at last follow-up. So cartilage extracellular matrix deposition shows adequate implant quality for MACT at the time of implantation and justifies the use for treatment of large cartilage defects. ${ }^{64}$

\section{Treatment recommendations for chondral injuries}

In their review, Niemeyer et $\mathrm{al}^{65}$ give a concise overview on important scientific background and the results of clinical studies discussing advantages and disadvantages of ACI and other cartilage treatment options. They describe the biology
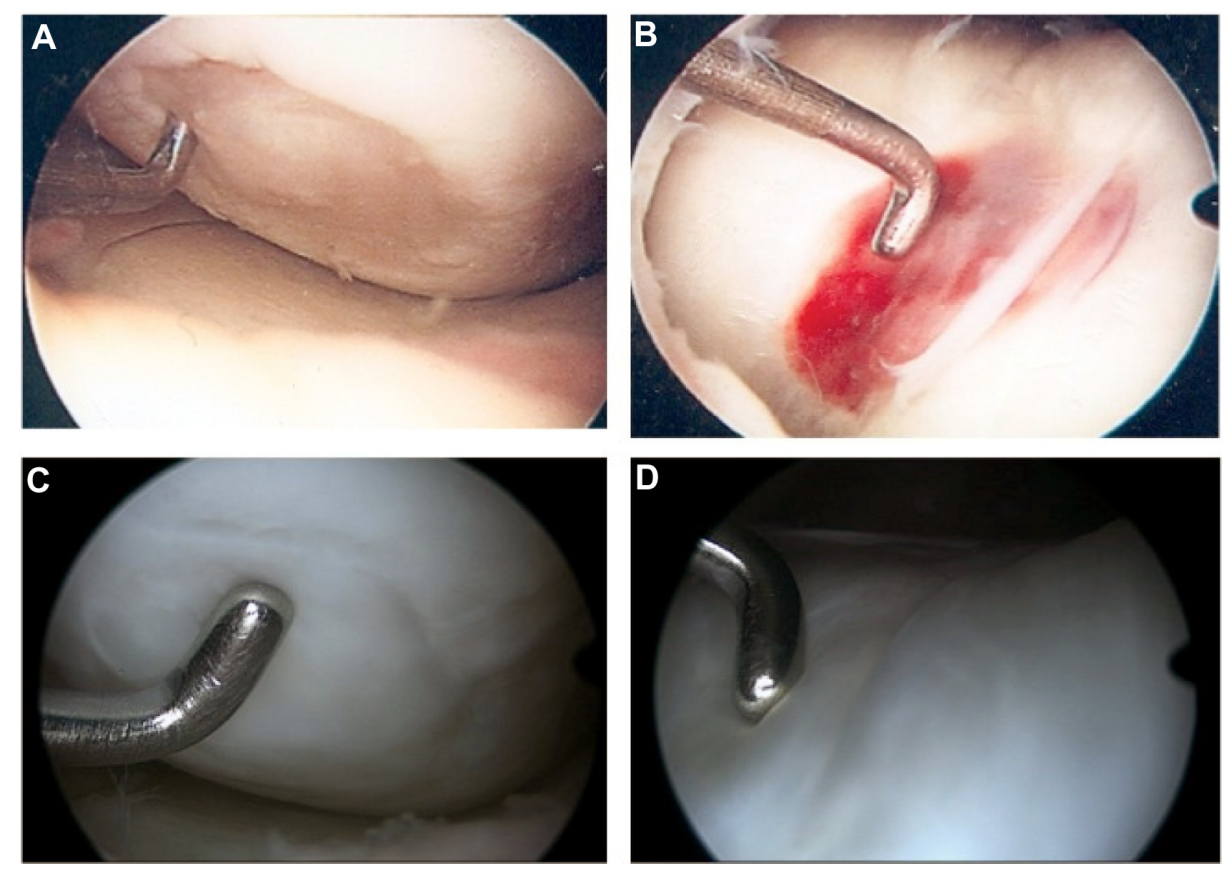

Figure I Different repair mechanisms of regenerative treatment procedures (MACT compared to microfracture).

Notes: Case of a 42-year-old patient with two chondral lesions (ICRS Grade 4) in the left knee. The defect of the medial femoral condyle was treated by matrix-associated $\mathrm{ACl}$ and in the trochlea femoris by microfracture. (A and B) During high tibial osteotomy for axis correction 8 weeks after index cartilage treatment an arthroscopy of the left knee was performed. (A and $\mathbf{B}$ ) clearly show the different repair mechanisms of the specific cartilage treatments. At 8 weeks after matrix-associated ACl, a thin cell layer covers the treated cartilage defect of the medial femoral condyle (A). At the same time point, a bloody superclot formation can be seen after microfracture in the trochlea femoris. (C and D) One year after cartilage treatment, again an arthroscopy of the left knee was performed during implant removal. Both defects were filled completely with a biomechanically favorable and more nativelike cartilage repair tissue after matrix-associated $\mathrm{ACl}(\mathbf{C})$ compared to microfracture (D).

Abbreviations: MACT, matrix-guided autologous chondrocyte transplantation; ICRS, International Cartilage Repair Society; ACI, autologous chondrocyte implantation. 
and function of healthy articular cartilage, the present state of knowledge concerning potential consequences of primary cartilage lesions, and the suitable indication for ACI. On the basis of current evidence, an indication for ACI is given for symptomatic cartilage defects starting from defect sizes of more than 3-4 $\mathrm{cm}^{2}$, in the case of young and active sports patients at $2.5 \mathrm{~cm}^{2}$. Smaller lesions are supposed to be treated by bone marrow stimulating techniques like microfracturing. However, the status of the subchondral bone should influence the decision-making process for cartilage therapy. Smaller defects with pathologies of the whole osteochondral unit are best treated with OAT. For large and deep osteochondral lesions, a combination of MACT and bone augmentation techniques is the favorable treatment option.

\section{Future perspectives in treatment of chondral injuries}

As all regenerative treatment options show not only advantages but also limiting disadvantages, research activities are performed to improve different aspects like tissue quality and functional outcome over time (Table 1).

\section{Developments in bone marrow stimulating techniques}

Regarding the microfracture technique, coverage of the prepared and treated chondral defect site by a biomaterial is becoming more and more popular. To overcome the shortcomings of the microfracture technique, this enhanced procedure was first described by Bark et al. ${ }^{66}$ The autologous matrix-induced chondrogenesis (AMIC) reveals promising results in terms of functional outcome. In a perspective study, Gille et $\mathrm{al}^{67}$ investigated 27 patients up to 62 months, with a mean defect size of $4.2 \mathrm{~cm}^{2}$. Approximately $87 \%$ were satisfied with an increase in functional outcome scores like International Cartilage Repair Society, Tegner, Cincinnati, etc. ${ }^{67}$ In another study, the same authors found a significant decrease of pain in the VAS (visual analog scale) at 1 and 2 years postoperatively. ${ }^{68}$ Kusano et al ${ }^{69}$ also detected significant improvements in functional scores and VAS after 29 months, but magnetic resonance imaging (MRI) findings showed generally incomplete or inhomogeneous tissue filling. Comparing AMIC with the original microfracturing technique, Anders et $\mathrm{al}^{70}$ found no significant differences in the IKDC or Cincinnati score at 1 or 2 year follow-up. A recent study has shown an improvement in repair tissue quality by enhancing microfracture with a chitosan-based biomaterial (BST-CarGel; Piramal, Laval, QC, Canada). ${ }^{71}$ Mixed with autologous blood, it stabilizes the clot and enhances marrow-derived repair in the microfractured cartilage lesion. Using this technique, Stanish et $\mathrm{al}^{71}$ saw an equivalent clinical benefit compared to microfracturing alone, but a greater defect filling and superior repair tissue quality in MRI evaluation. Further studies and long-term results will show whether enhanced microfracture techniques are really capable of overcoming the shortcomings of the original procedure. However, it is in doubt whether the modifications make microfracture-based techniques more appropriate for the treatment of large size chondral defects.

Another development in bone marrow stimulation techniques is microdrilling. In an animal model, Chen et $\mathrm{al}^{20}$

Table I Perspectives in regenerative cartilage treatment

\begin{tabular}{|c|c|c|c|}
\hline $\begin{array}{l}\text { Cartilage treatment } \\
\text { techniques }\end{array}$ & Developments & Advantages & Disadvantages \\
\hline \multirow[t]{3}{*}{ Microfracture } & Coverage of the & Improvement of chondrogenic & Still limited for treatment of large defects \\
\hline & microfractured defect site & differentiation & \\
\hline & Microdrilling & More controllable defect treatment & $\begin{array}{l}\text { No clinical data of improvement } \\
\text { compared to the conventional technique }\end{array}$ \\
\hline Osteochondral treatment & Biphasic scaffolds & $\begin{array}{l}\text { Restoration of the whole } \\
\text { osteochondral unit }\end{array}$ & $\begin{array}{l}\text { Limitation in subchondral bone } \\
\text { remodeling }\end{array}$ \\
\hline \multirow[t]{8}{*}{$\mathrm{ACl}$} & Smart biomaterials & $\begin{array}{l}\text { Reduction of degeneration products } \\
\text { Induction of regeneration }\end{array}$ & No clinical long-term data \\
\hline & Bioreactor application & Preconditioning of the cell-seeded & Expensive \\
\hline & & scaffold & No long-term data \\
\hline & Allogenic chondrocytes & One-step procedure & Regulatory burdens \\
\hline & Autologous MSCs & High potential for differentiation & Regulatory burdens \\
\hline & & One-step procedure & \\
\hline & Regenerative treatment & Filling a treatment gap & Expensive technique \\
\hline & under early OA conditions & Delay the need for arthroplasty & \\
\hline
\end{tabular}

Note: Recent or future development options for improvement of different cartilage treatment techniques and their potential advantages or disadvantages. Abbreviations: $\mathrm{ACl}$, autologous chondrocyte implantation; MSCs, mesenchymal stem cells; OA, osteoarthritis. 
compared this "micro-Pridie"-drilling method with standard microfracturing histologically. While microfracture caused compacted bone around the created holes that sealed them off from viable bone marrow, drilling cleanly removed bone from the holes and provided access channels to marrow stroma. Heat necrosis was not seen in the drilling group. However, there is no prospective clinical study that shows superior outcome of the drilling technique compared to microfracturing. ${ }^{21}$

\section{Developments in $\mathrm{ACl}$}

Controlled randomized studies and meta-analyses showed that ACI is the treatment of choice for large cartilage defects, showing superior outcome compared to other regenerative procedures. ${ }^{65}$ The technique has been improved over the last years to address some limitations of the first-generation ACI. By using matrix-associated ACI, the revision rate could be reduced compared to the periosteal covered ACI. ${ }^{72}$ As described earlier, complications like graft hypertrophy related to the periosteal flap or insufficient regenerative cartilage related to restricted function of the injected chondrocytes were addressed by the matrix-associated technique. ${ }^{35}$ By the development of the matrix-guided technique, the complexity and morbidity of the procedure could be reduced. The first long-term data, 10 years after MACT for treatment of chondral defects, show significantly improved clinical and radiological outcome measures in patients with symptomatic traumatic cartilage lesions. ${ }^{73}$ The use of scaffolds in a threedimensional culture system helps to optimize chondrocyte transplantation from not only a biological but also from a surgical point of view. However, delamination or disturbed fusion to the surrounding native cartilage and subchondral bone are still problems for the third-generation ACI. Niethammer et $\mathrm{al}^{74}$ reported a revision rate of $23.4 \%$ after MACT. The reasons were bone marrow edema, arthrofibrosis, and partial graft deficiency. In these cases, arthroscopically performed revision surgery resulted in a significantly improved clinical outcome.

Preconditioning of the cell-seeded scaffolds prior to implantation into the chondral defect might be another way of improvement for ACI procedures. Crawford et al ${ }^{52,75}$ described a novel technique using tissue-engineered bovine type I collagen scaffold seeded with autologous chondrocytes, which were preconditioned in a bioreactor including the application of hydrostatic pressure prior to implantation. In clinical trials, the authors saw advantages for treatment of medium- and large-sized chondral lesions after 2 years, with respect to the IKDC, KOOS, and Short Form-36.
Long-term results are needed to analyze a possible advantage compared to other scaffold-based ACI procedures without biomechanical preconditioning.

\section{Smart biomaterials for cartilage therapy}

Further improvements of the currently used biomaterials are needed to reduce degradation products that might affect the implanted cells. Recently developed materials have improved their biocharacteristics and biocompatibility, so that their degradation products cause less damage to repair and native tissue than synthetic materials. ${ }^{76}$

Smart biomaterials should not only provide proper adjustment to tissue environment but also induce integrative regeneration of the repair tissue. ${ }^{77}$ Biomatrices could be informative for cells in various ways. The three-dimensional architecture could guide cells toward mechanically crucial spots within the tissue and allow them to form chondrons. ${ }^{78,79}$ Scaffolds can offer a matrix for an organized cell distribution to mimic even the site-specific mechanical properties at different compartments of the knee. Additionally, the matrix polymers utilized could be metabolically active themselves, either within the polymer or from the degradation products released in controlled resorption. For example, collagen peptides may contain bioactive sequences like integrins, ${ }^{80}$ or hyaluronan may act chondroprotectively. Furthermore, the scaffold could have variable attachment sites for informative biomolecules such as growth hormones or even relevant genetic information (plasmids). ${ }^{77}$ In vivo polymerizing hydrogels with or without cells can be injected into the defect site in a less invasive arthroscopic way, offering surgical and biological potential advantages. ${ }^{81}$

For pathologies involving the subchondral bone, several authors highlighted the need for biphasic scaffolds for restoration of the whole osteochondral unit and to mimic the different biological and functional requirements. Preliminary results of some osteochondral scaffolds are promising; ${ }^{82}$ however, there are reports that show a missing integration at the subchondral bone level with the formation of cysts and edema after implantation of artificial osteochondral plugs for treatment of focal osteochondral lesions. ${ }^{83}$

Currently, most of the ACI procedures have to be performed in a two-step procedure with a period of cell culture in between. Two subsequent operations and consecutively high costs are the disadvantages of these regenerative treatments, and so a one-step procedure would be preferable.

The aim of future investigations with smart biomaterials might be the "in situ" regeneration of cartilage defects by a singlestep procedure. Chondroinductive and chondroconductive 
scaffolds could help to simplify the procedure and reduce comorbidity and probably recovery time. Matrices might be rehydrated with autologous stem cells that migrate into the scaffold to regenerate the defect.

\section{Potential cell types for treatment of chondral injuries}

Appropriate cell types might also affect the complexity of $\mathrm{ACI}$ and simplify surgical procedures.

Allogenic chondrocytes can help reduce donor site morbidity. In combination with a biocompatible and chondroinductive matrix, allogenic chondrocytes harvested from neonatal donors or from donor's knee joints within 24 hours of death may be used in a single-stage procedure ${ }^{84}$ Preliminary results demonstrated a safe and effective treatment for cartilage defects with a mean lesion size of $2.7 \mathrm{~cm}^{2}$. Clinical outcomes showed significant improvement over baseline and favorable histological repair tissue 2 years postoperatively. Dhollander et $\mathrm{a}^{85}$ reported midterm results after implantation of alginate beads containing human mature allogenic chondrocytes in cartilage lesions of the knee. Twenty-one patients were followed for an average period of 6.3 years, and a significant improvement in WOMAC (Western Ontario and McMaster Universities Arthritis Index) scores and VAS could be observed. However, four failures occurred, and MRI evaluation with the MOCART (magnetic resonance observation of cartilage repair tissue) score only showed moderate scores.

Autologous mesenchymal stem cells (MSCs) are a potential cell source for a single-step cell-based treatment of large cartilage defect. MSCs have a better proliferation rate than chondrocytes and a high potential for differentiation, including chondrogenesis. Nejadnik et $\mathrm{a}^{86}$ analyzed the clinical outcome of patients treated with autologous MSCs compared to patients treated with first-generation ACI for large cartilage defects in the knee. After 2 years, a similar functional outcome regarding IKDC, Lysholm, or Tegner score was found. The authors concluded that using bone marrow-derived MSCs in cartilage repair is as effective as chondrocytes for articular cartilage repair. In addition, it required one less knee surgery, reduced costs, and minimized donor site morbidity. However, at the moment in some countries, regulatory burdens might be a problem for implementing the use of autologous MSCs in daily clinical practice.

\section{Regenerative treatment of early osteoarthritis}

With increasing knowledge, $\mathrm{ACI}$ has become a more routinely used technique with predictable outcome and results.
Improvements may help to push the limits of the procedure. In their survey, Li et al ${ }^{87}$ found that orthopedic surgeons complain about a treatment gap for patients with early osteoarthritis of the knee. Regenerative treatment options are especially in the focus of research to fill this gap for these younger patients. In a systematic review, de Windt et a ${ }^{88}$ analyzed 502 patients in the age group 36-57 years who were treated by articular cartilage repair for early osteoarthritis. An ACI was performed in $75 \%$ of the patients. In the follow-up only up to 9 years, $2.5 \%-6.5 \%$ of the patients had to be converted to an arthroplasty. Particularly, ACI shows regenerative potential under early osteoarthritis conditions. Hollander et al ${ }^{89}$ analyzed biopsies of the repair tissue 16 months after ACI of patients with or without radiological signs of osteoarthritis. Interestingly, $67 \%$ of the biopsies of patients with osteoarthritis revealed development of hyaline cartilage, whereas only $36 \%$ of biopsies of patients without signs of osteoarthritis showed articular cartilage formation. Minas et a ${ }^{90}$ followed 153 patients (mean age: 38.3 years) up to 11 years after treatment with ACI for early osteoarthritis. Approximately $8 \%$ had to be converted to arthroplasty. However, $50 \%-75 \%$ of the remaining patients improved in WOMAC subscales. ACI treatment in patients with early degenerative changes resulted in reduction in pain and increase in function, so $92 \%$ were able to delay the need for arthroplasty. ${ }^{90}$ Hence, ACI may offer improved quality of life for young patients with osteoarthritic changes. However, further studies have to be performed to clarify the limitations of regenerative treatment options under early osteoarthritis conditions.

\section{Conclusion}

With increasing knowledge, ACI has become a more routinely used technique with predictable outcome and results. As research activities are increasing in the field of regenerative joint therapy, recent developments help to overcome remaining limitations step by step. Simplification of regulatory burdens is needed to transfer rising knowledge and developments into daily clinical practice.

\section{Disclosure}

The authors report no conflicts of interest in this work.

\section{References}

1. Sellards RA, Nho SJ, Cole BJ. Chondral injuries. Curr Opin Rheumatol. 2002;14(2):134-141.

2. Widuchowski W, Widuchowski J, Trzaska T. Articular cartilage defects: study of 25,124 knee arthroscopies. Knee. 2007;14(3):177-182.

3. Curl WW, Krome J, Gordon ES, Rushing J, Smith BP, Poehling GG. Cartilage injuries: a review of 31,516 knee arthroscopies. Arthroscopy. 1997;13(4):456-460. 
4. Brittberg M, Lindahl A, Nilsson A, Ohlsson C, Isaksson O, Peterson L. Treatment of deep cartilage defects in the knee with autologous chondrocyte transplantation. $N$ Engl J Med. 1994;331(14):889-895.

5. Marcacci M, Filardo G, Kon E. Treatment of cartilage lesions: what works and why? Injury. 2013;44(Suppl 1):S11-S15.

6. Mithoefer K, McAdams T, Williams RJ, Kreuz PC, Mandelbaum BR. Clinical efficacy of the microfracture technique for articular cartilage repair in the knee: an evidence-based systematic analysis. Am J Sports Med. 2009;37(10):2053-2063.

7. Steadman JR, Briggs KK, Rodrigo JJ, Kocher MS, Gill TJ, Rodkey WG. Outcomes of microfracture for traumatic chondral defects of the knee: average 11-year follow-up. Arthroscopy. 2003;19(5):477-484.

8. Kon E, Filardo G, Berruto M, et al. Articular cartilage treatment in high-level male soccer players: a prospective comparative study of arthroscopic second-generation autologous chondrocyte implantation versus microfracture. Am J Sports Med. 2011;39(12):2549-2557.

9. Brown WE, Potter HG, Marx RG, Wickiewicz TL, Warren RF. Magnetic resonance imaging appearance of cartilage repair in the knee. Clin Orthop Relat Res. 2004(422):214-223.

10. Behrens P, Bosch U, Bruns J, et al. Indikations- und Durchführungsempfehlungen der Arbeitsgemeinschaft Geweberegeneration und Gewebeersatz" zur Autologen Chondrozyten-Transplantation (ACT) [Indications and implementation of recommendations of the working group "Tissue Regeneration and Tissue Substitutes" for autologous chondrocyte transplantation (ACT)]. Zeitschrift fur Orthopadie und ihre Grenzgebiete. 2004;142(5):529-539. German.

11. Gobbi A, Nunag P, Malinowski K. Treatment of full thickness chondral lesions of the knee with microfracture in a group of athletes. Knee Surg Sports Traumatol Arthrosc. 2005;13(3):213-221.

12. Gudas R, Kalesinskas RJ, Kimtys V, et al. A prospective randomized clinical study of mosaic osteochondral autologous transplantation versus microfracture for the treatment of osteochondral defects in the knee joint in young athletes. Arthroscopy. 2005;21(9):1066-1075.

13. Kreuz PC, Erggelet C, Steinwachs MR, et al. Is microfracture of chondral defects in the knee associated with different results in patients aged 40 years or younger? Arthroscopy. 2006;22(11):1180-1186.

14. Mithoefer K, Hambly K, Della Villa S, Silvers H, Mandelbaum BR. Return to sports participation after articular cartilage repair in the knee: scientific evidence. Am J Sports Med. 2009;37(Suppl 1):167S-176S.

15. Kon E, Filardo G, Condello V, et al. Second-generation autologous chondrocyte implantation: results in patients older than 40 years. $\mathrm{Am}$ J Sports Med. 2011;39(8):1668-1675.

16. Von Keudell A, Atzwanger J, Forstner R, Resch H, Hoffelner T, Mayer M. Radiological evaluation of cartilage after microfracture treatment: a long-term follow-up study. Eur J Radiol. 2012;81(7):1618-1624.

17. Nehrer S, Spector M, Minas T. Histologic analysis of tissue after failed cartilage repair procedures. Clin Orthop Relat Res. 1999;365: 149-162.

18. Fortier LA, Cole BJ, Mcllwraith CW. Science and animal models of marrow stimulation for cartilage repair. J Knee Surg. 2012;25(1):3-8.

19. Muller B, Kohn D. Indication for and performance of articular cartilage drilling using the Pridie method. Orthopade. 1999;28(1):4-10. German.

20. Chen H, Sun J, Hoemann CD, et al. Drilling and microfracture lead to different bone structure and necrosis during bone-marrow stimulation for cartilage repair. J Orthop Res. 2009;27(11):1432-1438.

21. Hunziker EB, Lippuner K, Keel MJ, Shintani N. An educational review of cartilage repair: precepts and practice - myths and misconceptions progress and prospects. Osteoarthritis Cartilage. 2015;23(3): $334-350$.

22. Gudas R, Stankevicius E, Monastyreckiene E, Pranys D, Kalesinskas RJ. Osteochondral autologous transplantation versus microfracture for the treatment of articular cartilage defects in the knee joint in athletes. Knee Surg Sports Traumatol Arthrosc. 2006;14(9):834-842.

23. Jakob RP, Franz T, Gautier E, Mainil-Varlet P. Autologous osteochondral grafting in the knee: indication, results, and reflections. Clin Orthop Relat Res. 2002;(401):170-184.
24. Hangody L, Fules P. Autologous osteochondral mosaicplasty for the treatment of full-thickness defects of weight-bearing joints: ten years of experimental and clinical experience. J Bone Joint Surg Am. 2003;85-A (Suppl 2):25-32.

25. Robert H. Chondral repair of the knee joint using mosaicplasty. Orthop Traumatol Surg Res. 2011;97(4):418-429.

26. Bader S, Miniaci A. Mosaicplasty. Orthopedics. 2011;34(9): e491-e493.

27. Ohlendorf C, Tomford WW, Mankin HJ. Chondrocyte survival in cryopreserved osteochondral articular cartilage. J Orthop Res. 1996; 14(3):413-416.

28. Gomoll AH, Filardo G, Almqvist FK, et al. Surgical treatment for early osteoarthritis. Part II: allografts and concurrent procedures. Knee Surg Sports Traumatol Arthrosc. 2012;20(3):468-486.

29. Czitrom AA, Keating S, Gross AE. The viability of articular cartilage in fresh osteochondral allografts after clinical transplantation. $J$ Bone Joint Surg Am. 1990;72(4):574-581.

30. Jamali AA, Hatcher SL, You Z. Donor cell survival in a fresh osteochondral allograft at twenty-nine years. A case report. $J$ Bone Joint Surg Am. 2007;89(1):166-169.

31. Bentley G, Biant LC, Carrington RW, et al. A prospective, randomised comparison of autologous chondrocyte implantation versus mosaicplasty for osteochondral defects in the knee. J Bone Joint Surg Br. 2003;85(2):223-230.

32. Peterson L, Minas T, Brittberg M, Lindahl A. Treatment of osteochondritis dissecans of the knee with autologous chondrocyte transplantation: results at two to ten years. J Bone Joint Surg Am. 2003;85-A(Suppl 2): $17-24$.

33. Peterson L, Brittberg M, Kiviranta I, Akerlund EL, Lindahl A. Autologous chondrocyte transplantation. Biomechanics and long-term durability. Am J Sports Med. 2002;30(1):2-12.

34. Peterson L, Minas T, Brittberg M, Nilsson A, Sjogren-Jansson E, Lindahl A. Two- to 9-year outcome after autologous chondrocyte transplantation of the knee. Clin Orthop. 2000;374:212-234.

35. Harris JD, Siston RA, Brophy RH, Lattermann C, Carey JL, Flanigan DC. Failures, re-operations, and complications after autologous chondrocyte implantation - a systematic review. Osteoarthritis Cartilage. 2011;19(7):779-791.

36. Pietschmann MF, Niethammer TR, Horng A, et al. The incidence and clinical relevance of graft hypertrophy after matrix-based autologous chondrocyte implantation. Am J Sports Med. 2012;40(1):68-74.

37. Vavken P, Samartzis D. Effectiveness of autologous chondrocyte implantation in cartilage repair of the knee: a systematic review of controlled trials. Osteoarthritis Cartilage. 2010;18(6):857-863.

38. Harris JD, Siston RA, Pan X, Flanigan DC. Autologous chondrocyte implantation: a systematic review. J Bone Joint Surg Am. 2010;92(12): 2220-2233.

39. Mithoefer K, Williams RJ 3rd, Warren RF, et al. The microfracture technique for the treatment of articular cartilage lesions in the knee. A prospective cohort study. J Bone Joint Surg Am. 2005;87(9):1911-1920.

40. Behrens P, Bitter T, Kurz B, Russlies M. Matrix-associated autologous chondrocyte transplantation/implantation (MACT/MACI) - 5-year follow-up. Knee. 2006;13(3):194-202.

41. Pietschmann MF, Horng A, Niethammer T, et al. Cell quality affects clinical outcome after MACI procedure for cartilage injury of the knee. Knee Surg Sports Traumatol Arthrosc. 2009;17(11):1305-1311.

42. Nehrer S, Dorotka R, Domayer S, Stelzeneder D, Kotz R. Treatment of full-thickness chondral defects with hyalograft $\mathrm{C}$ in the knee: a prospective clinical case series with 2 to 7 years' follow-up. Am J Sports Med. 2009;37(Suppl 1):81S-87S.

43. Filardo G, Kon E, Di Martino A, Iacono F, Marcacci M. Arthroscopic second-generation autologous chondrocyte implantation: a prospective 7-year follow-up study. Am J Sports Med. 2011;39(10):2153-2160.

44. Schneider U, Rackwitz L, Andereya S, et al. A prospective multicenter study on the outcome of type I collagen hydrogel-based autologous chondrocyte implantation (CaReS) for the repair of articular cartilage defects in the knee. Am J Sports Med. 2011;39(12):2558-2565. 
45. Vanlauwe J, Saris DB, Victor J, Almqvist KF, Bellemans J, Luyten FP. Five-year outcome of characterized chondrocyte implantation versus microfracture for symptomatic cartilage defects of the knee: early treatment matters. Am J Sports Med. 2011;39(12):2566-2574.

46. Niemeyer P, Steinwachs M, Erggelet C, et al. Autologous chondrocyte implantation for the treatment of retropatellar cartilage defects: clinical results referred to defect localisation. Arch Orthop Trauma Surg. 2008; 128(11):1223-1231.

47. Niemeyer P, Koestler W, Sudkamp NP. Probleme und Komplikationen chirurgischer Verfahren zur Behandlung vollschichtiger Knorpeldefekte am Kniegelenk. [Problems and complications of surgical techniques for treatment of full-thickness cartilage defects]. Z Orthop Unfall. 2011;149(1):45-51. German.

48. Niemeyer P, Salzmann GM, Hirschmuller A, Sudkamp NP. Einflussfaktoren auf das Behandlungsergebnis nach autologer Knorpelzelltransplantation (ACT) am Kniegelenk [Factors that influence clinical outcome following autologous chondrocyte implantation for cartilage defects of the knee]. Z Orthop Unfall. 2012;150(1):83-88. German.

49. Anders S, Lechler P, Grifka J, Schaumburger J. Therapie lokaler Knorpelschäden im Patellofemoralgelenk [Repair of local cartilage defects in the patellofemoral joint]. Orthopade. 2011;40(10):885-888, 890-885. German.

50. Vasiliadis HS, Lindahl A, Georgoulis AD, Peterson L. Malalignment and cartilage lesions in the patellofemoral joint treated with autologous chondrocyte implantation. Knee Surg Sports Traumatol Arthrosc. 2011;19(3):452-457.

51. Basad E, Ishaque B, Bachmann G, Sturz H, Steinmeyer J. Matrixinduced autologous chondrocyte implantation versus microfracture in the treatment of cartilage defects of the knee: a 2-year randomised study. Knee Surg Sports Traumatol Arthrosc. 2010;18(4):519-527.

52. Crawford DC, DeBerardino TM, Williams RJ 3rd. NeoCart, an autologous cartilage tissue implant, compared with microfracture for treatment of distal femoral cartilage lesions: an FDA phase-II prospective, randomized clinical trial after two years. J Bone Joint Surg Am. 2012;94(11):979-989.

53. Saris DB, Vanlauwe J, Victor J, et al. Characterized chondrocyte implantation results in better structural repair when treating symptomatic cartilage defects of the knee in a randomized controlled trial versus microfracture. Am J Sports Med. 2008;36(2):235-246.

54. Minas T, Gomoll AH, Rosenberger R, Royce RO, Bryant T. Increased failure rate of autologous chondrocyte implantation after previous treatment with marrow stimulation techniques. Am J Sports Med. 2009;37(5):902-908.

55. Pestka JM, Bode G, Salzmann G, Sudkamp NP, Niemeyer P. Clinical outcome of autologous chondrocyte implantation for failed microfracture treatment of full-thickness cartilage defects of the knee joint. $\mathrm{Am}$ J Sports Med. 2012;40(2):325-331.

56. Jungmann PM, Salzmann GM, Schmal H, Pestka JM, Sudkamp NP, Niemeyer P. Autologous chondrocyte implantation for treatment of cartilage defects of the knee: what predicts the need for reintervention? Am J Sports Med. 2012;40(1):58-67.

57. Zaslav K, Cole B, Brewster R, et al. A prospective study of autologous chondrocyte implantation in patients with failed prior treatment for articular cartilage defect of the knee: results of the Study of the Treatment of Articular Repair (STAR) clinical trial. Am J Sports Med. 2009;37(1):42-55.

58. Rosenberger RE, Gomoll AH, Bryant T, Minas T. Repair of large chondral defects of the knee with autologous chondrocyte implantation in patients 45 years or older. Am J Sports Med. 2008;36(12):2336-2344.

59. Peterson L, Vasiliadis HS, Brittberg M, Lindahl A. Autologous chondrocyte implantation: a long-term follow-up. Am J Sports Med. 2010;38(6):1117-1124.

60. Niemeyer P, Kostler W, Salzmann GM, Lenz P, Kreuz PC, Sudkamp NP. Autologous chondrocyte implantation for treatment of focal cartilage defects in patients age 40 years and older: a matched-pair analysis with 2-year follow-up. Am J Sports Med. 2010;38(12):2410-2416.
61. Knutsen G, Engebretsen L, Ludvigsen TC, et al. Autologous chondrocyte implantation compared with microfracture in the knee. A randomized trial. J Bone Joint Surg Am. 2004;86-A(3):455-464.

62. Henderson I, Lavigne P, Valenzuela H, Oakes B. Autologous chondrocyte implantation: superior biologic properties of hyaline cartilage repairs. Clin Orthop Relat Res. 2007;455:253-261.

63. LaPrade RF, Bursch LS, Olson EJ, Havlas V, Carlson CS. Histologic and immunohistochemical characteristics of failed articular cartilage resurfacing procedures for osteochondritis of the knee: a case series. Am J Sports Med. 2008;36(2):360-368.

64. Zellner J, Angele P, Zeman F, Kujat R, Nerlich M. Is the transplant quality at the time of surgery adequate for matrix-guided autologous cartilage transplantation? A pilot study. Clin Orthop Relat Res. 2013;471(9):2852-2861.

65. Niemeyer P, Andereya S, Angele P, et al. Stellenwert der autologen Chondrozytentransplantation (ACT) in der Behandlung von Knorpelschäden des Kniegelenks - Empfehlungen der AG Klinische Geweberegeneration der DGOU [Autologous chondrocyte implantation (ACI) for cartilage defects of the knee: a guideline by the working group "Tissue Regeneration" of the German Society of Orthopaedic Surgery and Traumatology (DGOU)]. Zeitschrift fur Orthopadie und Unfallchirurgie. 2013;151(1):38-47. German.

66. Bark S, Piontek T, Behrens P, Mkalaluh S, Varoga D, Gille J. Enhanced microfracture techniques in cartilage knee surgery: fact or fiction? World J Orthop. 2014;5(4):444-449.

67. Gille J, Schuseil E, Wimmer J, Gellissen J, Schulz AP, Behrens P. Midterm results of Autologous Matrix-Induced Chondrogenesis for treatment of focal cartilage defects in the knee. Knee Surg Sports Traumatol Arthrosc. 2010;18(11):1456-1464.

68. Gille J, Behrens P, Volpi P, et al. Outcome of Autologous Matrix Induced Chondrogenesis (AMIC) in cartilage knee surgery: data of the AMIC Registry. Arch Orthop Trauma Surg. 2013;133(1):87-93.

69. Kusano T, Jakob RP, Gautier E, Magnussen RA, Hoogewoud H, Jacobi M. Treatment of isolated chondral and osteochondral defects in the knee by autologous matrix-induced chondrogenesis (AMIC). Knee Surg Sports Traumatol Arthrosc. 2012;20(10):2109-2115.

70. Anders S, Volz M, Frick H, Gellissen J. A randomized, controlled trial comparing autologous matrix-induced chondrogenesis (AMIC ${ }^{\circledR}$ ) to microfracture: analysis of 1- and 2-year follow-up data of 2 centers. Open Orthop J. 2013;7:133-143.

71. Stanish WD, McCormack R, Forriol F, et al. Novel scaffold-based BST-CarGel treatment results in superior cartilage repair compared with microfracture in a randomized controlled trial. J Bone Joint Surg Am. 2013;95(18):1640-1650.

72. Niemeyer P, Pestka JM, Kreuz PC, et al. Characteristic complications after autologous chondrocyte implantation for cartilage defects of the knee joint. Am J Sports Med. 2008;36(11):2091-2099.

73. Aldrian S, Zak L, Wondrasch B, et al. Clinical and radiological long-term outcomes after matrix-induced autologous chondrocyte transplantation: a prospective follow-up at a minimum of 10 years. Am J Sports Med. 2014;42(11):2680-2688.

74. Niethammer T, Valentin S, Ficklscherer A, Gulecyuz M, Pietschmann M, Muller P. Revision surgery after third generation autologous chondrocyte implantation in the knee. Int Orthop. 2015;39(8):1615-1622.

75. Crawford DC, Heveran CM, Cannon WD Jr, Foo LF, Potter HG. An autologous cartilage tissue implant NeoCart for treatment of grade III chondral injury to the distal femur: prospective clinical safety trial at 2 years. Am J Sports Med. 2009;37(7):1334-1343.

76. Caterson EJ, Nesti LJ, Li WJ, et al. Three-dimensional cartilage formation by bone marrow-derived cells seeded in polylactide/alginate amalgam. J Biomed Mater Res. 2001;57(3):394-403.

77. Gaissmaier C, Koh JL, Weise K, Mollenhauer JA. Future perspectives of articular cartilage repair. Injury. 2008;39(Suppl 1):S114-S120.

78. Mollenhauer JA. Perspectives on articular cartilage biology and osteoarthritis. Injury. 2008;39(Suppl 1):S5-S12.

79. Poole CA. Articular cartilage chondrons: form, function and failure. J Anat. 1997;191(Pt 1):1-13. 
80. Mobasheri A, Carter SD, Martin-Vasallo P, Shakibaei M. Integrins and stretch activated ion channels; putative components of functional cell surface mechanoreceptors in articular chondrocytes. Cell Biol Int. 2002;26(1):1-18.

81. Filardo G, Kon E, Roffi A, Di Martino A, Marcacci M. Scaffold-based repair for cartilage healing: a systematic review and technical note. Arthroscopy. 2013;29(1):174-186.

82. Kon E, Filardo G, Di Martino A, et al. Clinical results and MRI evolution of a nano-composite multilayered biomaterial for osteochondral regeneration at 5 years. Am J Sports Med. 2014;42(1):158-165.

83. Gelber PE, Batista J, Millan-Billi A, et al. Magnetic resonance evaluation of TruFit ${ }^{\circledR}$ plugs for the treatment of osteochondral lesions of the knee shows the poor characteristics of the repair tissue. Knee. 2014;21(4):827-832.

84. Farr J, Tabet SK, Margerrison E, Cole BJ. Clinical, radiographic, and histological outcomes after cartilage repair with particulated juvenile articular cartilage: a 2-year prospective study. Am J Sports Med. 2014;42(6):1417-1425.

85. Dhollander AA, Verdonk PC, Lambrecht S, et al. Midterm results of the treatment of cartilage defects in the knee using alginate beads containing human mature allogenic chondrocytes. Am J Sports Med. 2012;40(1):75-82.
86. Nejadnik H, Hui JH, Feng Choong EP, Tai BC, Lee EH. Autologous bone marrow-derived mesenchymal stem cells versus autologous chondrocyte implantation: an observational cohort study. Am J Sports Med. 2010;38(6):1110-1116.

87. Li CS, Karlsson J, Winemaker M, Sancheti P, Bhandari M. Orthopedic surgeons feel that there is a treatment gap in management of early OA: international survey. Knee Surg Sports Traumatol Arthrosc. 2014;22(2):363-378

88. de Windt TS, Vonk LA, Brittberg M, Saris DB. Treatment and prevention of (early) osteoarthritis using articular cartilage repair-fact or fiction? A systematic review. Cartilage. 2013;4(3 Suppl):5S-12S.

89. Hollander AP, Dickinson SC, Sims TJ, et al. Maturation of tissue engineered cartilage implanted in injured and osteoarthritic human knees. Tissue Eng. 2006;12(7):1787-1798.

90. Minas T, Gomoll AH, Solhpour S, Rosenberger R, Probst C, Bryant T. Autologous chondrocyte implantation for joint preservation in patients with early osteoarthritis. Clin Orthop Relat Res. 2010;468(1): 147-157.

\section{Publish your work in this journal}

Orthopedic Research and Reviews is an international, peer-reviewed, open access journal focusing on the patho-physiology of the musculoskeletal system, trauma, surgery and other corrective interventions to restore mobility and function. Advances in new technologies, materials, techniques and pharmacological agents are particularly welcome. The journal welcomes original research, clinical studies, reviews \& evaluations, expert opinion and commentary, case reports and extended reports. The manuscript management system is completely online and includes a very quick and fair peer-review system, which is all easy to use. Visit http://www.dovepress. com/testimonials.php to read real quotes from published authors. 